\title{
Taxonomy and distribution of the genus Amphicteis (Polychaeta: Ampharetidae) collected by the BIOICE project in Icelandic waters
}

\author{
Julio Parapar ${ }^{* a}$, Gudmundur V. Helgason ${ }^{\mathrm{b}}$, Igor Jirkov ${ }^{\mathrm{c}}$ \& Juan Moreira ${ }^{\mathrm{d}}$ e \\ a Departamento de Bioloxía Animal, Bioloxía Vexetal e Ecoloxía, Facultade de Ciencias, \\ Universidade da Coruña, 15008, A Coruña, Spain; \\ ${ }^{\mathrm{b}}$ Institute of Biology, University of Iceland, Sturlugata 7, IS-101, Reykjavik, Iceland; \\ ${ }^{\mathrm{c}}$ Department of Hydrobiology, Biological Faculty, Moscow State University, Moscow, Russia; \\ ${ }^{\mathrm{d}}$ Estación de Bioloxía Mariña da Graña, Universidade de Santiago de Compostela, Rúa da Ribeira 1, \\ A Graña, E-15590 Ferrol, Spain; \\ e Departamento de Biología (Zoología), Facultad de Ciencias, Universidad Autónoma de Madrid, \\ Cantoblanco, E-28049 Madrid, Spain
}

Journal of Natural History Vol. 45, Nos. 23-24, June 2011, 1477-1499

Received 28 Jun 2010, Accepted 24 Jan 2011, Published online: 09 May 2011

\section{To cite this article:}

Julio Parapar, Gudmundur V. Helgason , Igor Jirkov \& Juan Moreira (2011) Taxonomy and distribution of the genus Amphicteis (Polychaeta: Ampharetidae) collected by the BIOICE project in Icelandic waters, Journal of Natural History, 45:23-24, 1477-1499, DOI: $10.1080 / 00222933.2011 .558640$

This is an Accepted Manuscript of an article published by Taylor \& Francis in Journal of Natural History on 2011, available online: http://dx.doi.org/10.1080/00222933.2011.558640

\begin{abstract}
Based on material collected during the BIOICE project off Iceland, four species of polychaetous annelids belonging to the genus Amphicteis Grube, 1850 (Polychaeta: Ampharetidae) were found: Amphicteis gunneri, Amphicteis ninonae, Amphicteis vestis and Amphicteis wesenbergae sp. nov. The differences between A. gunneriand A. ninonae, two species usually confused in the literature, are reviewed. Amphicteis vestis is described from newly collected material and its taxonomy in relation to other ampharetid taxa with modified notopodia is discussed. Amphicteis wesenbergae sp. nov. is described; the new species is characterized by the presence of long, slender and evenly tapered paleae, and long dorsal cirri on thoracic and abdominal neuropodia. Several body characters with high value in Amphicteis taxonomy, particularly the dorsolateral protrusions of abdominal chaetigers called rudimentary notopodia, are reviewed using scanning electron microscopy. A key to species of the genus Amphicteis described or reported in European Boreo-Arctic waters is provided.
\end{abstract}

Keywords: Polychaeta, Ampharetidae, Amphicteis , Iceland, BIOICE 


\section{Introduction}

The genus Amphicteis Grube, 1850 is one of the most widely distributed and species-rich genera within the diverse family Ampharetidae Malmgren, 1866. Day (1964), Fauchald (1977) and Holthe (1986a) characterize the genus Amphicteis by the presence of four pairs of branchiae, paleae, smooth buccal tentacles, 17 thoracic chaetigers with notopodia (14 with uncinigerous tori) and 13-19 abdominal segments with uncinigerous pinnules and notopodial rudiments.

Since Holthe (1986b), who reported 18 genera of ampharetids in northeast Atlantic waters, there had been no review of this family in the northern waters of Europe until the study by Jirkov (2001Jirkov, IA. 2001. Polychaeta of the Arctic Ocean, Moscow: Yanus-K. (in Russian)) on Arctic Polychaeta. Recently, significant efforts have been underway to improve and standardize the general knowledge of this family through partial, but valuable, revisions (Jirkov 2008; Reuscher et al. 2009). Four species of Amphicteis were hitherto described or reported in European Boreo-Arctic waters (Hansson 1998); Bellan 2001; Jirkov 2001): Amphicteis gunneri (Sars, 1835), Amphicteis midas (Gosse, 1855), Amphicteis sundevalli Malmgren, 1866 and Amphicteis ninonae Jirkov, 1985.

The BIOICE (Benthic Invertebrates of Icelandic Waters) expeditions are part of an international, collaborative programme started in 1992, designed to conduct a thorough survey of the marine benthic fauna present in the 200-mile economic zone of Iceland. The BIOICE sampling area covers a depth range from 20 to $3500 \mathrm{~m}$ on both sides of the Greenland-Iceland-Faeroe Ridge (GIF Ridge), which is generally less than $500 \mathrm{~m}$ deep and constitutes the boundary between the relatively warm North Atlantic Ocean and the much colder Nordic seas of the Arctic Ocean (Weisshappel 2000; Brix and Svavarsson 2010). The polychaete material collected under this project has already been used to describe new taxa (Sanfilippo 2001; Sigvaldadóttir 2002; Chambers and Woodham 2003); papers devoted to the families Glyceridae, Goniadidae and Oweniidae have been published by Kirkegaard (2001) and Parapar (2003, 2006).

Examination of further polychaete material collected during those expeditions revealed the presence of four species of Amphicteis, namely A. gunneri, A. ninonae, A. vestis Hartman, 1965 and the new species A. wesenbergae sp. nov. Amphicteis vestis is reported for the first time in North Atlantic waters since its original description by Hartman (1965) in waters off New England and a new description is provided using scanning electron microscopy (SEM). Amphicteis wesenbergae sp. nov. is described. In addition, comments are provided to further elucidate the structure of different body parts with high value in the taxonomy of the genus Amphicteis.

\section{Materials and methods}

This study is based on material collected during the BIOICE expeditions. In total, 1789 specimens of the genus Amphicteis were sorted from 230 samples taken at stations located on both sides of the GIF Ridge, covering a depth range from 17 to $3018 \mathrm{~m}$ (Figure 1A).

Specimens were fixed in 10\% formalin buffered with borax, and preserved in $70 \%$ ethanol. Animals were sorted from samples by the staff at the Sandgerdi Marine Centre (SMC), and then identified at species level by the authors. The material examined is deposited in the collections of the Icelandic Museum of Natural History (IMNH, Reykjavik, Iceland), Museo Nacional de Ciencias Naturales (MNCN, Madrid, Spain), Zoologisk Museum (ZMUC, Copenhagen, Denmark). Data on bottom-water temperature, depth and coordinates used herein correspond to the start of each tow. Abiotic data of the samples studied from the BIOICE collection are available from the authors (G.V.H.) upon request. Specimens used for examination with SEM were prepared by critical point drying, covered with gold in 
a BAL-TEC SCD 004 evaporator, and examined and photographed under a JEOL JSM-6400 SEM at the SAI (University of A Coruña-UDC, Spain).

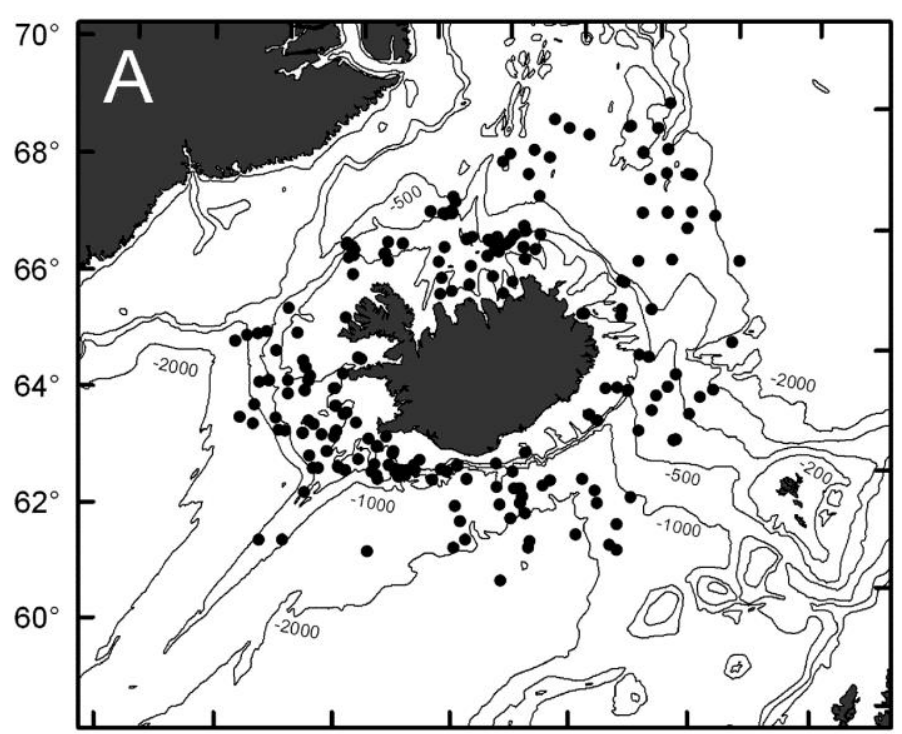

Figure 1. Distribution maps of total Amphicteis material examined (A), Amphicteis vestis (B) and Amphicteis wesenbergae sp. nov. (C).
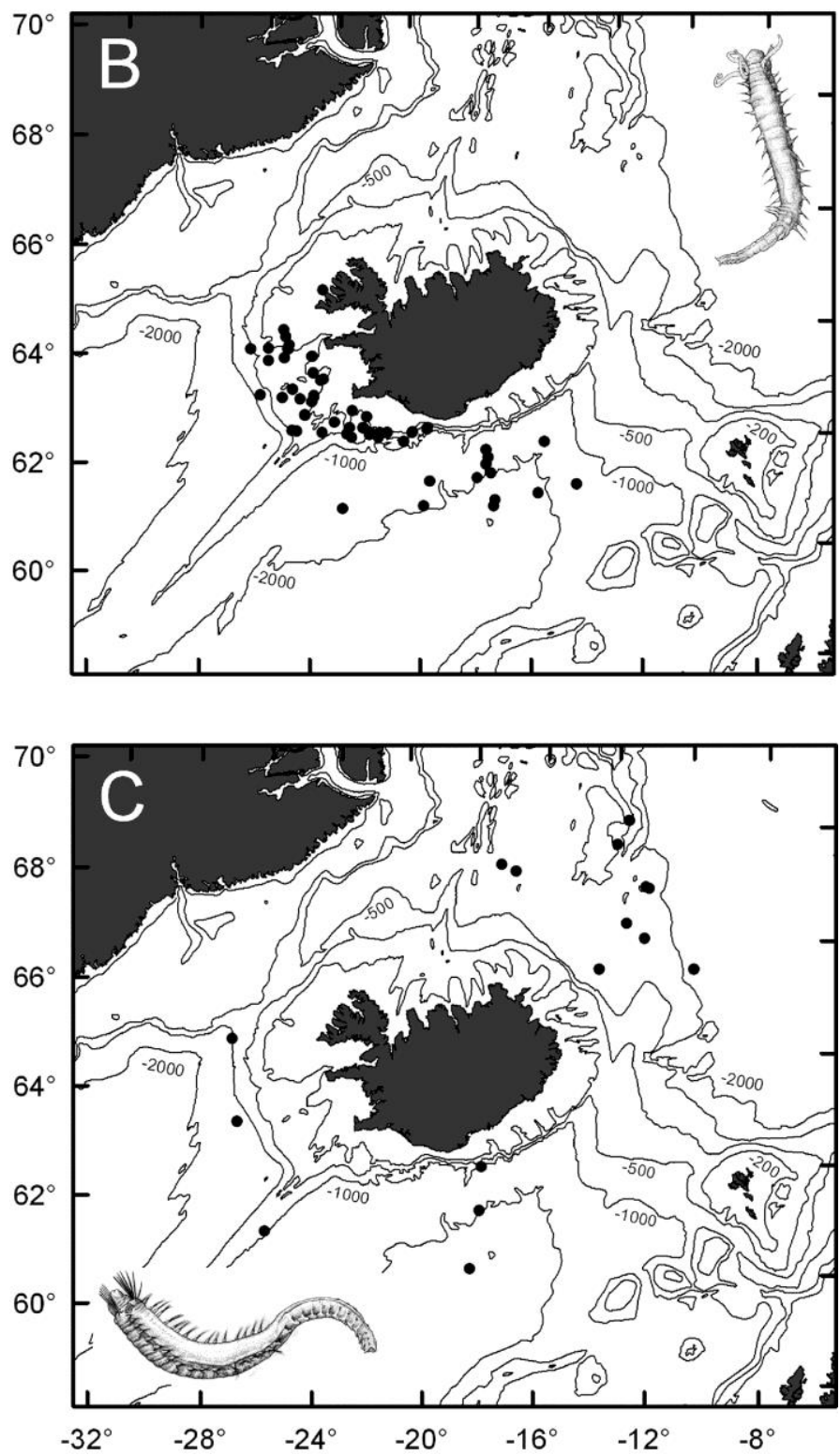


\section{Systematics}

Family AMPHARETIDAE Malmgren, 1866

Genus Amphicteis Grube, 1850

Type species

Amphicteis gunneri (Sars, 1835) as Amphitrite

\section{Diagnosis}

Prostomium with a pair of dorsal longitudinal ridges and a pair of transverse nuchal grooves. Four pairs of branchiae of variable shape (usually cirriform and sometimes foliaceous or pennate). Branchial ridge usually present and with a pair of nephridial pores. Paleae usually present and well developed; absent in some species. Buccal tentacles smooth. Seventeen thoracic chaetigers and 14 thoracic uncinigers. Thoracic notopodia with distal ventral cirrus. Fifteen to twenty abdominal chaetigers with uncinigerous pinnules and rudimentary notopodia. All thoracic neuropodia of thoracic type; all abdominal neuropodia of abdominal type. Thoracic and abdominal uncini with a single vertical row of teeth of similar size, pygidium with a pair of anal cirri.

\section{Remarks}

According to Hartman (1959) and Fauchald (1977), the genus Crossostoma Gosse, 1855 was traditionally considered invalid and a synonym of Amphicteis. However, Hartley (1985:309), when reestablishing the validity of A. midas (Gosse, 1855), the type species of the genus Crossostoma, recognized the interbranchial region as markedly different to that of the group of species close to the genotype Amphicteis gunneri(compare fig. 1 with fig. 3 in Hartley 1985) and therefore suggested that it was necessary to reconsider the status of Crossostoma. This suggestion has not been adopted in later works (Hartmann-Schröder, 1996), probably because Hartley's article was not included in Holthe's papers (1986a:88; 1986b:56), the latter constituting the reference works on the taxonomy of European Terebellomorpha. Only a revision of the genus in European waters could confirm or deny this possibility.

Jirkov (2001:439) considered characters such as the presence or absence of paleal chaetae, number of pairs of gills and number of thoracic uncinigers as of low taxonomic value in generic discrimination in the family Ampharetidae (see also Jirkov 2008:111). Therefore, Jirkov (2001:407) proposed PhyllamphicteisAugener, 1918 (two of four pairs of branchiae lamellate and originally described with 18 thoracic chaetigers, although re-examination of the holotype revealed only 17), Paramphicteis Caullery, 1944 (no paleae) and Pseudoamphicteis Hutchings, 1977 (papillose buccal tentacles and originally described with two pairs of branchiae but actually possessing four as revealed during re-examination of the paratype in London) as junior synonyms of Amphicteis. 
(Figures 2, 3, 4A-C, 5)

Amphitrite gunneri: Sars : 50-51, pl. 11, fig. 30a-d.

Amphicteis gunneri: Malmgren 1866:365-366, fig. 46; Fauvel 1927:231; Augener 1928:779 (partim?); Annenkova 1929:497, fig. 47 (partim); Holthe 1986a:89; Holthe 1986b:56-57, fig. 21, map 20; Hartmann-Schröder 1996:495; Jirkov 2001:471-472 (textfigure).

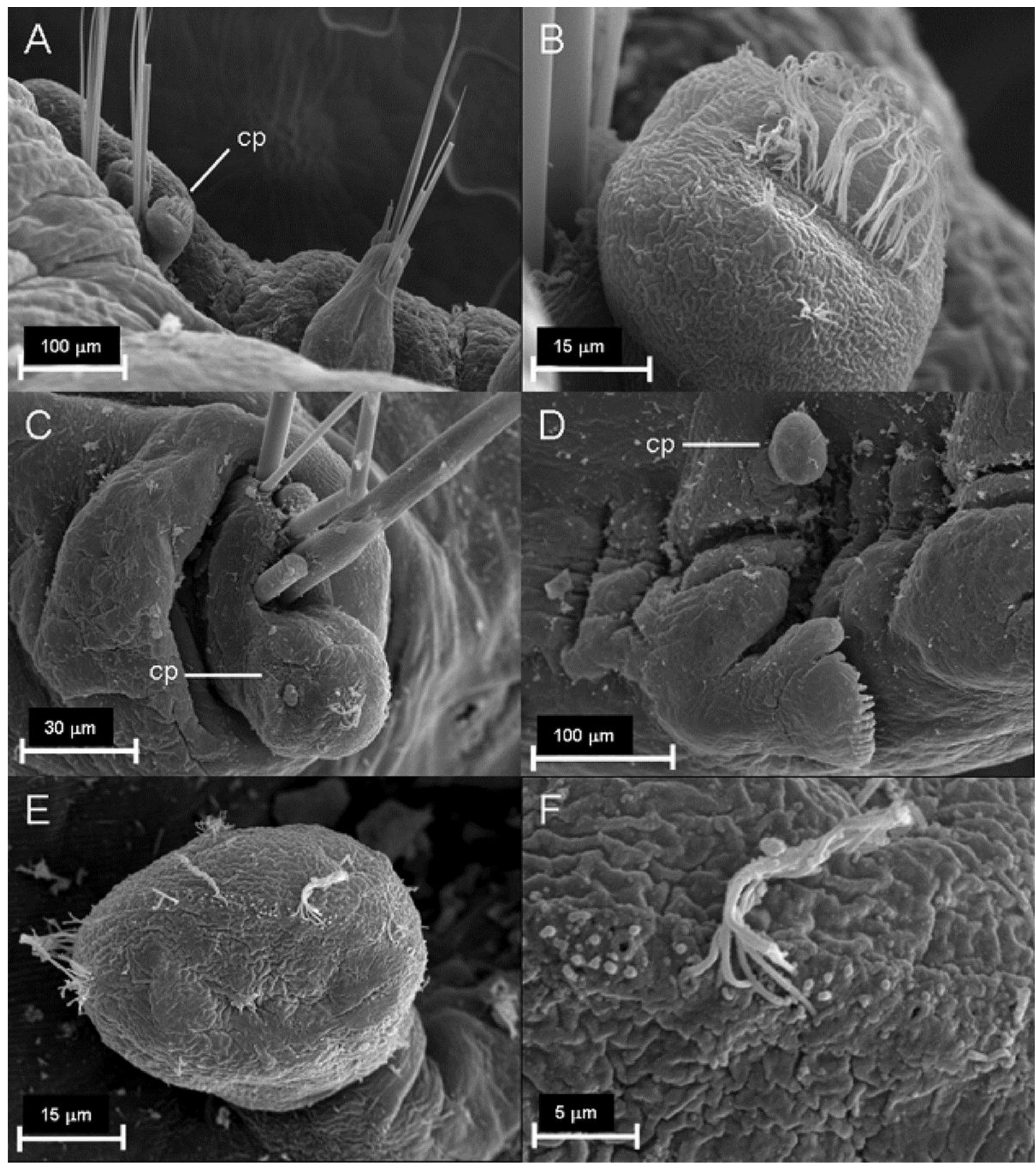

Figure 2. Amphicteis gunneri (Sars, 1835). Scanning electron micrographs from IMNH 24079. (A) Thoracic chaetigers 1-3, right side, dorsal view; (B) chaetiger 2, ventral clavate papilla; (C) chaetiger 17, notopodium; (D) mid-abdominal chaetiger; (E) mid-abdominal notopodial clavate papilla; (F) detail of ciliature of abdominal notopodial clavate papilla. Abbreviations: cp, clavate papilla. 


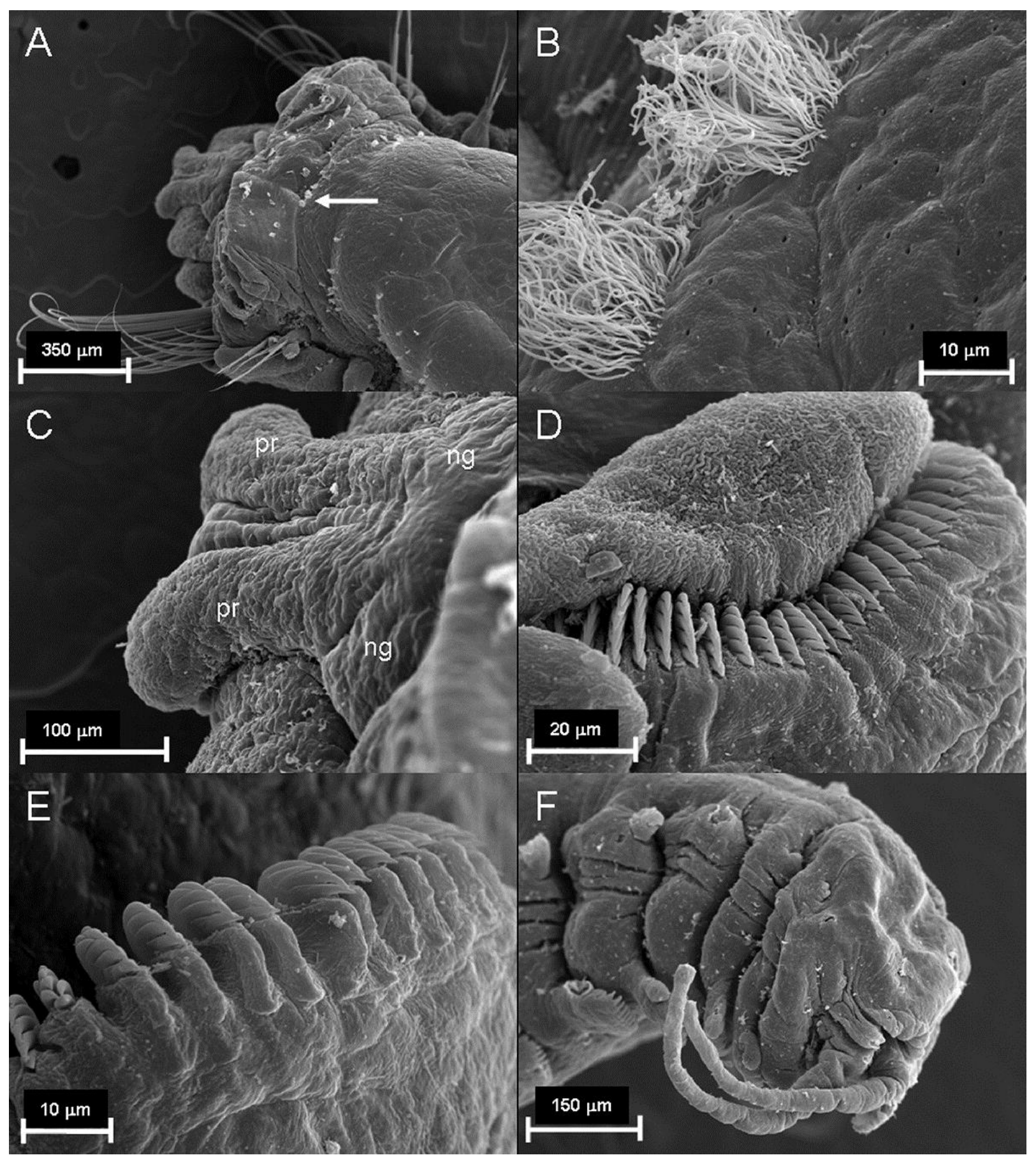

Figure 3. Amphicteis gunneri (Sars, 1835). Scanning electron micrographs from IMNH 24079. (A) Anterior end, dorsal view; (B) detail of dorsal ciliated tufts behind branchiae (arrow in A); (C) prostomium; (D) thoracic neuropodium and uncini; (E) abdominal uncini; (F) posterior region, lateral view. Abbreviations: pr, prostomial ridge, ng; nuchal groove. 


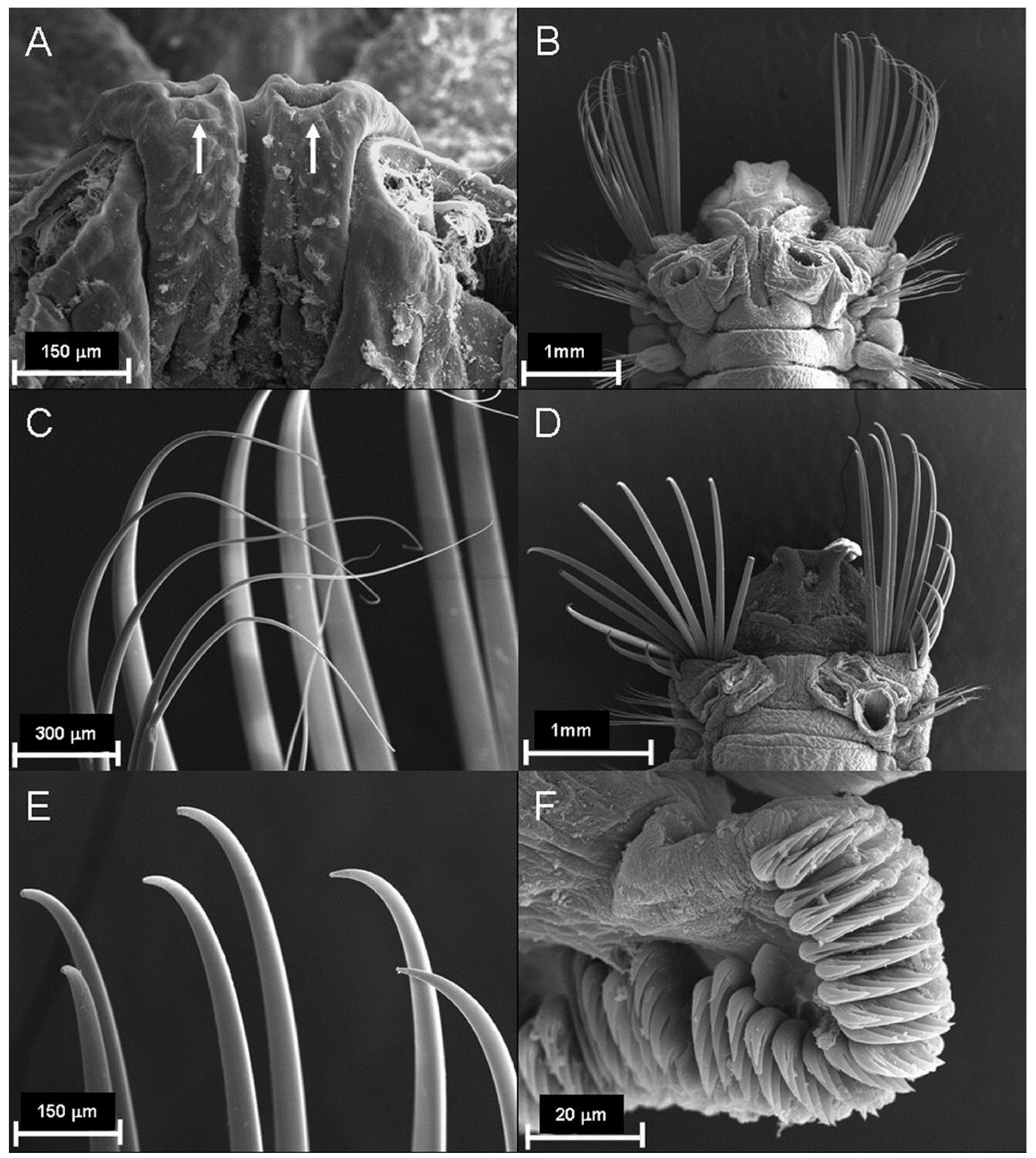

Figure 4. Amphicteis gunneri (Sars, 1835Sars, M. 1835. Beskrivelser og Iagttagelser over nogle maerkelige eller nye i Havet ved den Bergenske Kyst Levende Dyr af Polypernes, Acephalernes, Radiaternes, Annelidernes og Moluskernes Classer med en kort Oversigt over de hidtil af Forfatten sammesteds fundne Arter og deres Forekommen Bergen). Scanning electron micrographs from IMNH 24080. (A) Pair of nephridial pori (arrows) located on the ridge connecting the two groups of branchiae; (B) anterior end, dorsal view; (C) paleae, distal end. Amphicteis ninonae Jirkov, 1985, scanning electron micrographs, (IMNH 24081). (D) Anterior end, dorsal view; (E) paleae, distal end; (F) abdominal neuropodia with uncini. 


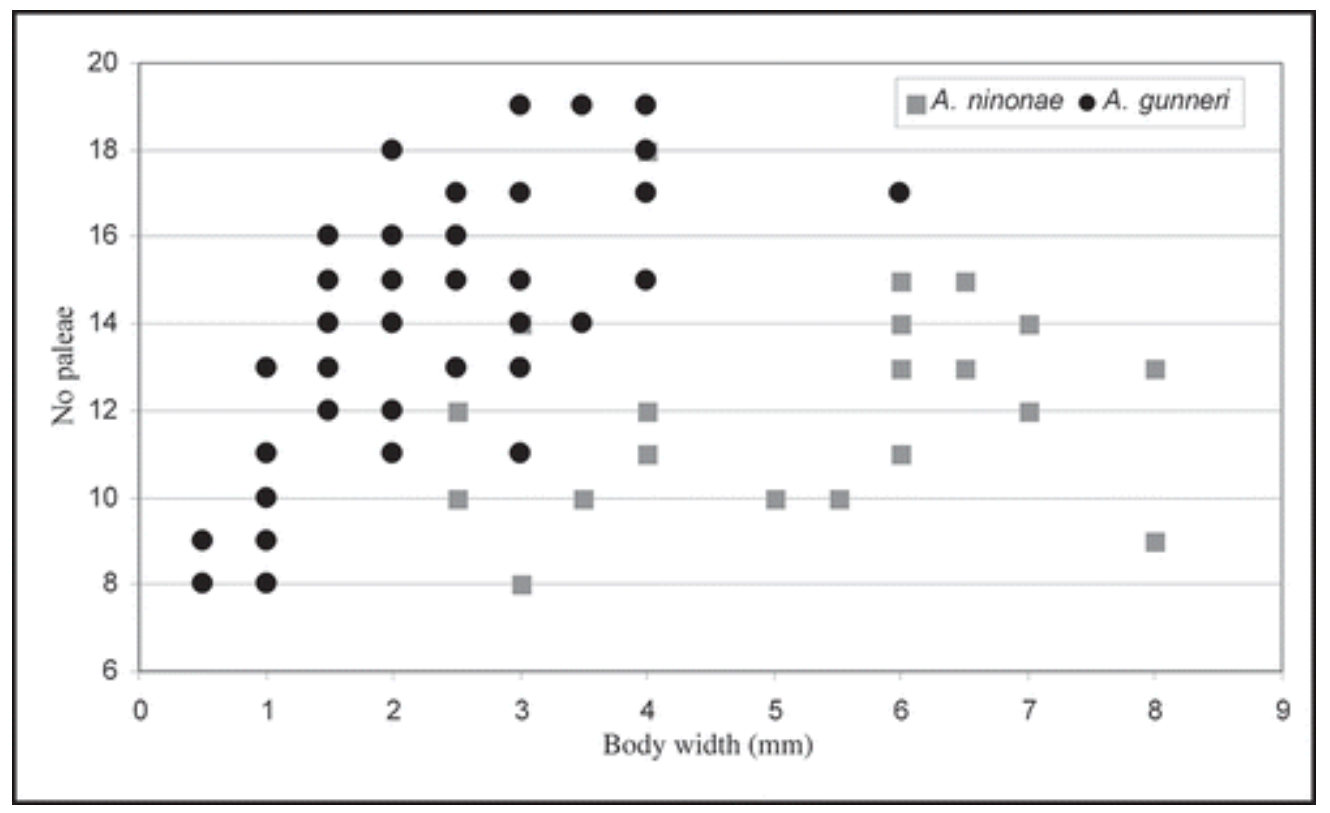

Figure 5. Number of paleae versus body width in BIOICE specimens of Amphicteis gunneri (Sars, 1835) and Amphicteis ninonae Jirkov, 1985.

\section{Material examined}

BIOICE sample 2049 (five specimens); 2075 (three); 2089 (six); 2090 (one); 2091 (two); 2094 (six); 2100 (12); 2102 (one); 2110 (one); 2111 (one); 2119 (five); 2129 (two); 2131 (one); 2154 (ten); 2161 (three); 2172 (one); 2209 (four); 2212 (eight); 2215 (one); 2216 (two); 2230 (two); 2236 (four); 2239 (one); 2241 (two); 2267 (two); 2277 (three); 2279 (one); 2282 (two); 2299 (one); 2310 (three); 2311 (one); 2314 (fourteen); 2324 (one); 2327 (three); 2328 (two); 2337 (twelve); 2348 (one); 2356 (one); 2358 (one); 2359 (one); 2363 (three); 2372 (two); 2374 (three); 2377 (seven); 2379 (one); 2380 (three); 2385 (one); 2387 (one); 2390 (four); 2397 (one); 2400 (one); 2403 (four); 2417 (two); 2418 (eight); 2423 (two); 2424 (one); 2430 (one); 2434 (two); 2435 (four); 2450 (one); 2466 (one); 2475 (one); 2522 (three); 2524 (two); 2526 (one); 2569 (one); 2572 (one); 2573 (one); 2592 (one); 2594 (two); 2595 (three); 2597 (one); 2603 (two); 2606 (nine); 2610 (four); 2612 (two); 2613 (one); 2615 (two); 2618 (two); 2619 (three); 2629 (one); 2642 (one); 2660 (one); 2666 (five); 2668 (one); 2673 (eight); 2697 (four); 2707 (four); 2710 (five); 2712 (14); 2713 (nine); 2717 (two); 2720 (four); 2743 (two); 2754 (two); 2769 (one); 2772 (ten); 2779 (one); 2791 (one); 2792 (six); 2813 (one); 2830 (one); 2849 (four); 2867 (seven); 2868 (one); 2872 (one); 2873 (four); 2877 (two); 2883 (three); 2884 (one); 2897 (three); 2909 (five); 2937 (eight); 2939 (one); 2965 (one); 2967 (two); 2970 (one); 2976 (three); 2978 (one); 2979 (three); 2983 (one); 3032 (one); 3050 (two); 3061 (one); 3062 (six); 3099 (two); 3114 (four); 3115 (one); 3127 (one); 3204 (three); 3216 (eleven); 3219 (four); 3238 (two); 3259 (two); 3260 (three); 3263 (one); 3280 (twelve); 3281 (three); 3501 (one); 3507 (two); 3518 (one); 3524 (one); 3527 (fourteen); 3528 (two); 3535 (six); 3538 (four); 3543 (eleven); 3544 (two); 3549 (two); 3550 (nine); 3558 (three); 3562 (one); 3591 (one); 3600 (one); 3608 (one); 3609 (one); 3610 (fourteen); 3621 (four); 3624 (fourteen); 3625 (twenty-five); 3627 (four); 3632 (fourteen); 3633 (seventeen); 3634 (four); 3635 (one); 3636 (seven); 3637 (six); 3638 (two); 3639 (one); 3643 (three); 3645 (five); 3648 (one); 3649 (fourteen); 3650 (one); 3652 (four); 3661 (one). 


\section{Occurrence}

In all, 628 specimens of A. gunneri (35.10\% of the total specimens examined) were collected in 176 BIOICE samples. According to its geographical distribution around Iceland, A. gunneri is present in high numbers at all depth and water temperature ranges; it seems to be absent only in shallower localities (less than $100 \mathrm{~m}$ depth). Depth range: $100-2613 \mathrm{~m}$; temperature range: -0.86 to $8.04^{\circ} \mathrm{C}$.

\section{Reported distribution}

Arctic and Boreal Atlantic, northeastern South America, Indian Ocean, Japan (Imajima 2001). Wesenberg-Lund (1951) reported this species from Iceland but regards it as rare, particularly on the northern coast.

Historically, most records of A. gunneri in the literature were not accompanied by descriptions and, when diagnoses were provided, these were usually short and uninformative because generic characters are commonly used to characterize the species. As previously stated by Hartley (1985:313) the confusing definition of the taxon makes it impossible to assess the distribution of A. gunneri from literature. Because of this, we agree with Hartley (1985:314) that a close re-examination of material attributed to the nominal species from different localities around the world will reveal a number of different species. Consequently, the true distribution of the species may be restricted to Arctic and North Atlantic European waters (see map in Jirkov 2001:471) with a southern boundary of distribution probably located in the English Channel. Therefore, until a global revision of Amphicteis is completed, the specific name A. gunneri should be used with caution.

\section{Remarks}

The transition from thorax to abdomen in Ampharetidae is marked by the loss of notochaetae and either the complete loss, or a reduction, of notopodia (Hutchings, 2000:206). The genus Amphicteis, along with other ampharetid genera such as Amage Malmgren, 1866, Amagopsis Chlebovitch, 1964, Amphisamytha Hessle, 1917, Anobothrus Levinsen,

1884, Asabellides Annenkova, 1929, Hobsonia Banse, 1979, Mexamage Fauchald, 1972, Paramage Caullery, 1944, Phyllampharete Hartman and Fauchald, 1971, and SamythaMalmgren, 1866, is characterized by the presence of so-called "rudimentary notopodia" in abdominal chaetigers (see Fauchald 1977:125; Holthe 1986b:56; Reuscher et al. 2009:5). The study of several BIOICE specimens of A. gunneri using SEM revealed that the abdominal notopodia are reduced entirely except for a clavate ciliated papilla, which is already present in the ventral part of thoracic notochaetal bundles in anterior chaetigers (Figure 2A-C), remaining as a solitary papilla in abdominal chaetigers (Figure 2D). Both in thorax and abdomen, those papillae are provided with an apical ciliated band (Figure 2B, E, F). This particular feature was previously suggested by Hartley (1985:310) for A. gunneri and for A. midas by Holthe (1986a:21). The location of these papillae at the base of the notopodium and the presence of apical ciliature might suggest some kind of sensory function linked to the role of the thoracic notochaetae in the movement of the animal inside the tube or in its irrigation (Holthe, 1986a:21). Hence, these structures would have remained in the abdominal region for that purpose, after evolutionary reduction of notopodial bundles in the genus. Perhaps linked to some kind of sensory perception, a high number of cuticle pori and a dense cover of ciliated tufts (Figure 3A, B) has been observed by SEM on the dorsal surface behind the branchiae.

The clavate papillae are referred to as rudimentary abdominal notopodia by many authors. Similar abdominal structures in other genera, such as Amage, may correspond to a formation of different origin from that proposed here for Amphicteis. The study of some BIOICE specimens of Amage auricula Malmgren, 1866Malmgren, AJ. 1866/1865. Nordiska Hafs-Annulater. Oefversigt af $K$ 
Vetenskaps-Akademiens Förhandlingar., 22: 355-410., the type species of the genus, did not reveal the presence of such papillae in the thoracic notopodia whereas rudimentary abdominal notopodia were much more noticeable. Both presence and nature of this character across ampharetid genera seem far from being definitively clarified, and the real value of this character in the taxonomy of this family can only be assessed after a thorough revision of the taxa endowed with this apparently diverse configuration.

The study of some specimens of A. gunneri under SEM also provided information on other diagnostic characters of the genus Amphicteis, namely the shape of the prostomium, thoracic and abdominal uncini and nephridial pori. The prostomium of A. gunneri (Figures 3C, 4B), A. ninonae (Figure 4D) and A. wesenbergae sp. nov. (Figure 10A) correspond well with Jirkov's Amphicteis-type, bearing a pair of longitudinal ridges and a pair of transverse nuchal grooves (Jirkov 2001). We agree with Reuscher et al. (2009:4) on the desirability of not using terms like "glandular" when describing these prostomial structures, because no histological studies support their use. Jirkov (2008:112) denies that these are of glandular nature, as many authors since Hessle (1917) have claimed. According to Mackie (1994) and Jirkov (2008:115), thoracic and abdominal neuropodia in Amphicteis differ in shape and uncini disposition, in that all thoracic uncini are of a thoracic type and all abdominal uncini are of abdominal type. Uncini are located in deep grooves in the thoracic uncinigers and on the edge of erect pinnules in the abdominal uncinigers; this feature (Figure 3D, E) is not exclusive to Amphicteis, but is shared with other genera of Ampharetidae. Thoracic and abdominal uncini in Amphicteis are characteristically provided with one vertical row of teeth of similar size (Figure 3D, E) and two anal cirri are inserted in the pygidium (Figure 3F). The nephridial papillae, always present in Terebellomorpha but often hardly visible (Jirkov 2008), open in a pair of nephridial pores located on the branchial ridge between both groups of branchiae (Figure 4A). The shape of the paleae, slender and evenly tapered (Figure 4B, C), distinguish A. gunneri from A. ninonae. Their number, which seems to be related to the body size in both species (Figure 5) was counted in some specimens revealing a similar range in A. gunneri (8-18) and A. ninonae (8-19).

Hartley (1985), after studying British and North Sea material, provided a redescription of A. gunneri and re-established A. midas (Gosse, 1855) as a valid species. He found that both species could be readily distinguished by morphological and ecological features. While A. midas is a shallowwater species $(<30 \mathrm{~m})$ in the studied area, A. gunneri is restricted to deeper waters. Amphicteis midas was not found among the BIOICE material, which was mostly collected from deep waters. The presence of A. midas in shallow coastal waters of Iceland cannot, however, be ruled out because it is likely that it might have previously been confused with A. gunneri in previous works in the same area, such as those by Saemundsson (1918), Ditlevsen (1929, 1937), Spärck (1937), Einarsson (1941Einarsson, H. 1941. Survey of benthonic animal communities of Faxa Bay (Iceland). Meddel Komm Danmarks Fisk Havundersøgelser, Fisk., 11: 1-46.) and Wesenberg-Lund (1950, 1951).

\section{Material examined}

BIOICE sample 2014 (four specimens); 2045 (one); 2046 (two); 2057 (one); 2070 (eight); 2085 (six); 2089 (one); 2094 (one); 2110 (one); 2113 (one); 2129 (three); 2145 (three); 2167 (one); 2174 (two); 2315 (one); 2319 (one); 2328 (eleven); 2359 (one); 2372 (one); 2572 (one); 2575 (three); 2576 (three); 2592 (one); 2594 (three); 2603 (two); 2604 (one); 2606 (four); 2610 (one); 2613 (one); 2619 (three); 2626 (one); 2627 (six); 2666 (four); 2673 (two); 2683 (one); 2792 (two); 2901 (one); 3099 (one); 3115 (one); 3252 (four); 3638 (five). 


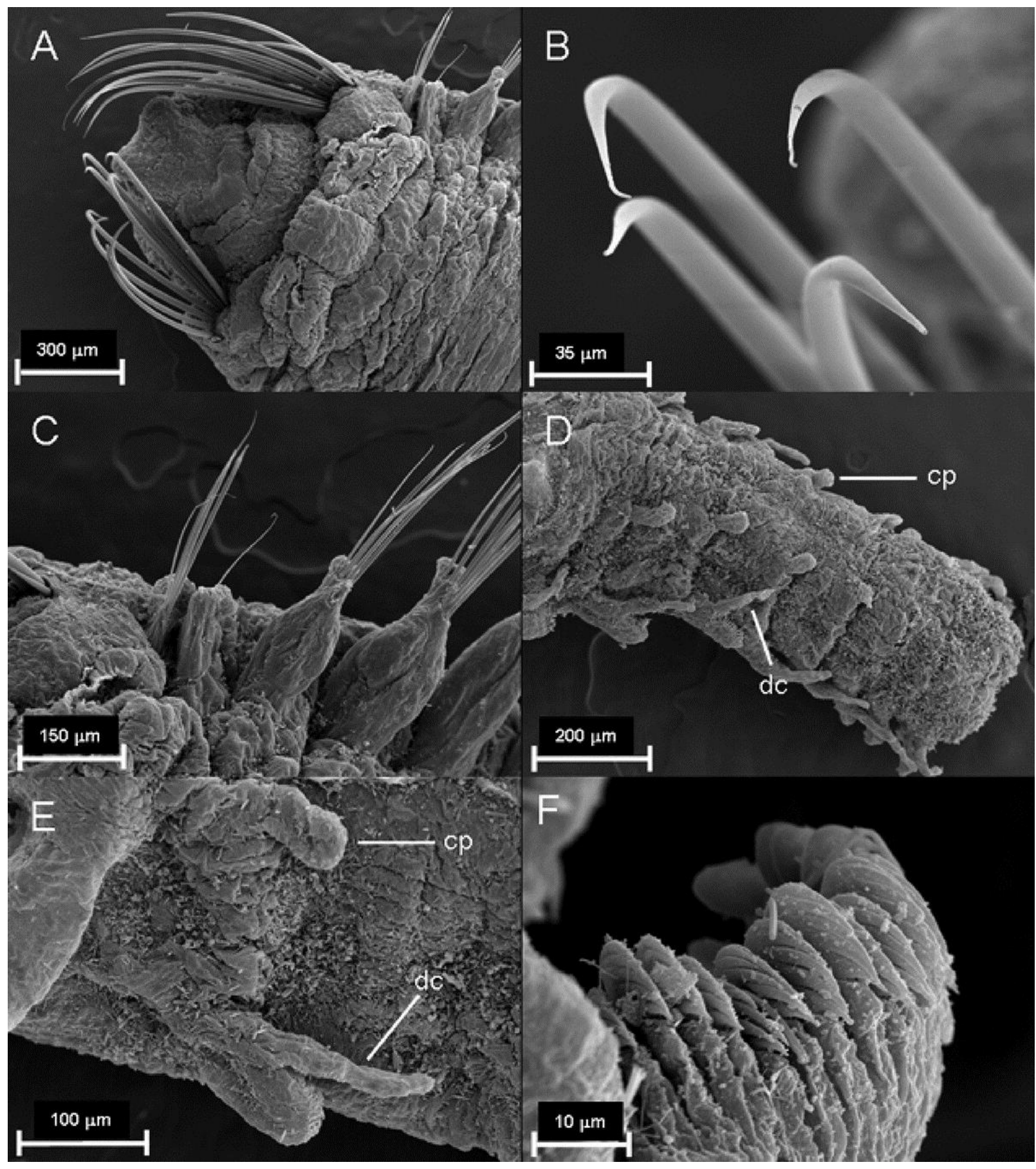

Figure 10. Amphicteis wesenbergae sp. nov. Scanning electron micrograph from paratype (ZMUC-POL-2148). (A) Anterior end, dorsal view; (B) paleae, distal end; (C) thoracic chaetigers 1-4, dorsal view; (D) posterior end, dorsal view; (E) abdominal mid-body chaetiger; (F) abdominal uncini. Abbreviations: cp, clavate papilla; dc, dorsal cirrus.

Amphicteis ninonae Jirkov, 1985

(Figures 4D-F, 5)

Amphicteis ninonae: Jirkov, 1985: 1894-1897 (textfigure); Jirkov, 2001: 472-473 (textfigure).

Amphicteis gunneri: Augener, 1928: 779 (partim?); Annenkova, 1929: 497, fig. 47 (partim); Ditlevsen, 1937: 39-40 (partim?) - non Sars, 1935. 


\section{Occurrence}

In all, 101 specimens of $A$. ninonae (5.65\% of the total) were collected in 40 BIOICE samples. In contrast to A. gunneri, this species seems to be restricted to the north and east coasts of Iceland. Depth range: $134-2067 \mathrm{~m}$; temperature range: -0.8 to $7.57^{\circ} \mathrm{C}$.

\section{Reported distribution}

Norwegian Sea, Arctic Seas (Hansson 1998; Deubel 2000). Our findings confirm the presence of this species in Icelandic waters, which was previously reported by Jirkov (2001).

\section{Remarks}

Amphicteis ninonae has often been confused with A. gunneri and to some extent perhaps also with A. midas. Nevertheless the low boreal distribution proposed for A. midas (see Hartley, 1985:311) against the high-latitude distribution of $A$. ninonae (see above), makes it difficult to believe that both species occur in sympatry. Following Jirkov (1985:1896; 2001:472), Amphicteis ninonae is primarily characterized by the colour (dark brown), and number (8-16) and shape (blunt tips) of paleae (Figure 4D, E and key below). We agree with Jirkov (1989:111) that A. ninonae has abdominal rudimentary notopodia. The BIOICE specimens are usually larger than those of A. gunneri and the number of paleae seems to have a weaker correlation with body size (Figure 5).

\section{Amphicteis vestis Hartman, 1965}

(Figures 1, 6-8)

Amphicteis vestis: Hartman, 1965 215-216, fig. 46.

\section{Material examined}

BIOICE sample 2213 (two specimens); 2215 (181); 2216 (two); 2221 (23); 2222 (five); 2226 (one); 2229 (one); 2230 (three); 2233 (one); 2236 (one); 2237 (twenty-nine); 2268 (one); 2273 (six); 2282 (twelve); 2285 (one); 2303 (eight); 2308 (twenty-five); 2311 (one); 2390 (one); 2391 (four), 2392 (three); 2393 (twelve); 2398 (one); 2400 (one); 2401 (thirty-six); 2417 (two); 2418 (six); 2423 (one); 2424 (fifteen); 2434 (five); 2435 (thirty-one); 2469 (one); 2475 (five); 2484 (one); 2712 (one); 2713 (one); 2716 (one); 2717 (sixteen); 2719 (one); 2856 (one); 2859 (three); 2860 (five); 2867 (one hundred and eleven); 2868 (fifty-eight); 2869 (five); 2873 (one); 2976 (three); 2979 (eight); 2983 (43); 3067 (eleven); 3072 (one); 3164 (one); 3500 (one); 3501 (four); 3505 (one); 3510 (three); 3519 (one); 3522 (one); 3524 (one); 3528 (one); 3539 (one); 3550 (sixteen); 3565 (one); 3608 (nineteen); 3617 (sixteen).

\section{Description}

Body between $1.4 \mathrm{~mm}$ and $10 \mathrm{~mm}$ long, and 0.2 to $0.5 \mathrm{~mm}$ wide. Thorax and abdomen well defined; thorax about twice width and three times length of abdomen (Figure 6); barely tapering towards posterior part. Prostomium pointed anteriorly with a pair of ciliated pits (nuchal organs?) located at both sides of anterior part (Figure 7A, B). No eyes seen. Buccal tentacles few and fairly large, with distal end expanded and ciliated on one side, but not papillated (Figure 7C-E). Four pairs of long and deciduous branchiae arranged in one outer row of three pairs and a fourth one in an inner position (Figure 7F). All branchiae of similar size; the inner one being thickest and the posteriormost of the outer row thinnest. Between 13 and 15 long and slender paleae with tapering ends. Seventeen thoracic chaetigers with notopodia with notochaetae; the posterior fourteen also with neuropodia with uncini located in a furrow 
distinctly off the neuropodial margin (Figure 8A). First abdominal segment with notopodia transformed in a double-winged expansion stretching across dorsum but with a large median notch (Figures 6, 8BD); inner margins of fans with ciliature (Figure 8D, E); no rows of papillae or ciliature seen in outer margins of fans. Thirteen abdominal segments; anterior ones longer than posterior ones, only with neuropodia with uncini at the very margin of the torus (Figure 8F). Pygidium with a pair of short lateral cirri. Notochaetae slightly flattened distally before tapering into slender tips. Thoracic and abdominal uncini slightly different in shape; thoracic uncini with three or four horizontal rows of three or four teeth above rostrum (Figure $8 \mathrm{~A}$ ); abdominal uncini with two horizontal rows of seven or eight teeth above rostrum (Figure $8 \mathrm{~F}$ ).

Colour in alcohol pale yellow. No tubes observed. Oocytes present in some specimens in the body cavity, visible through body wall.

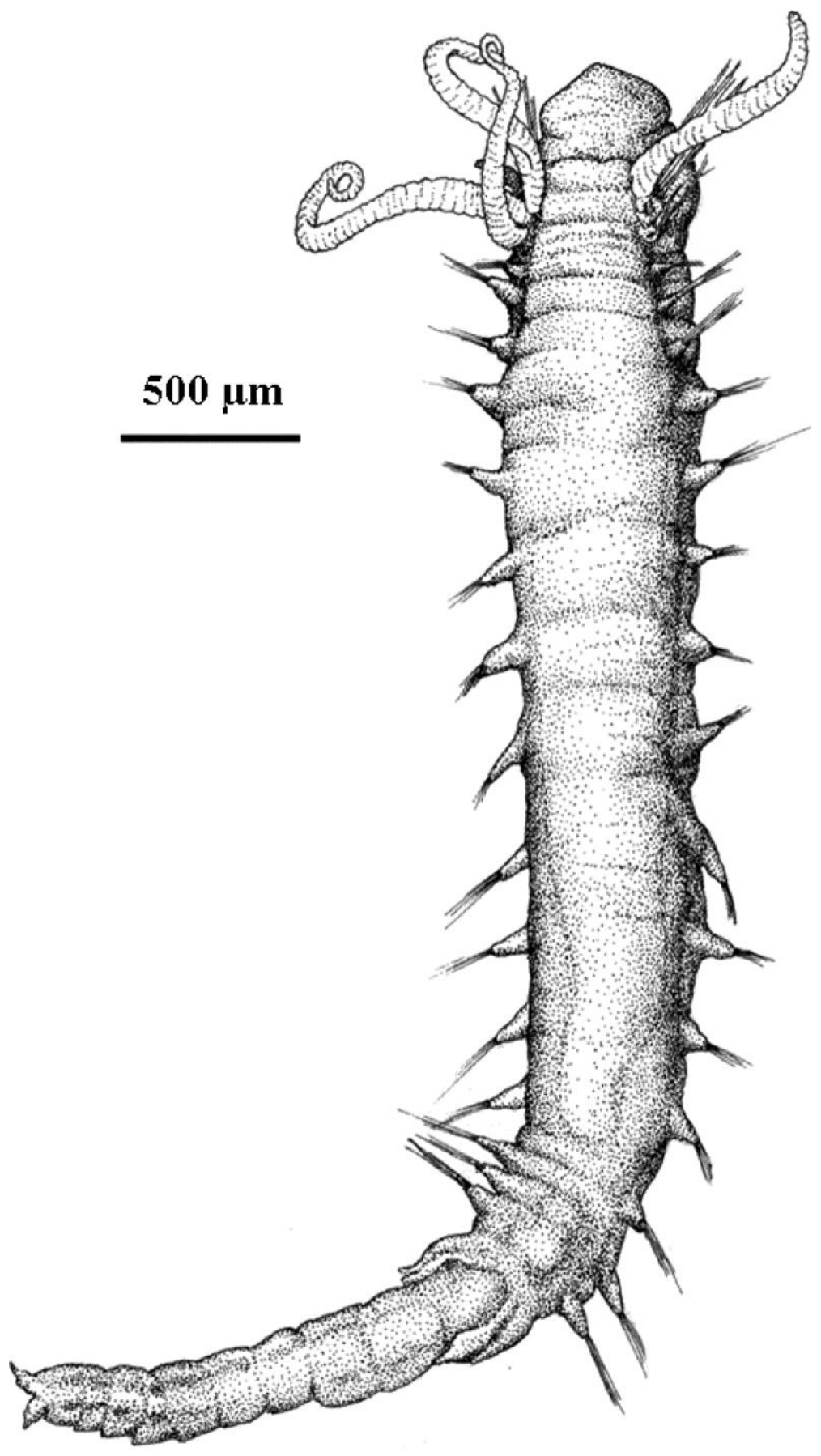

Figure 6. Dorsal view of Amphicteis vestis Hartman, 1965 (IMNH 24082). 


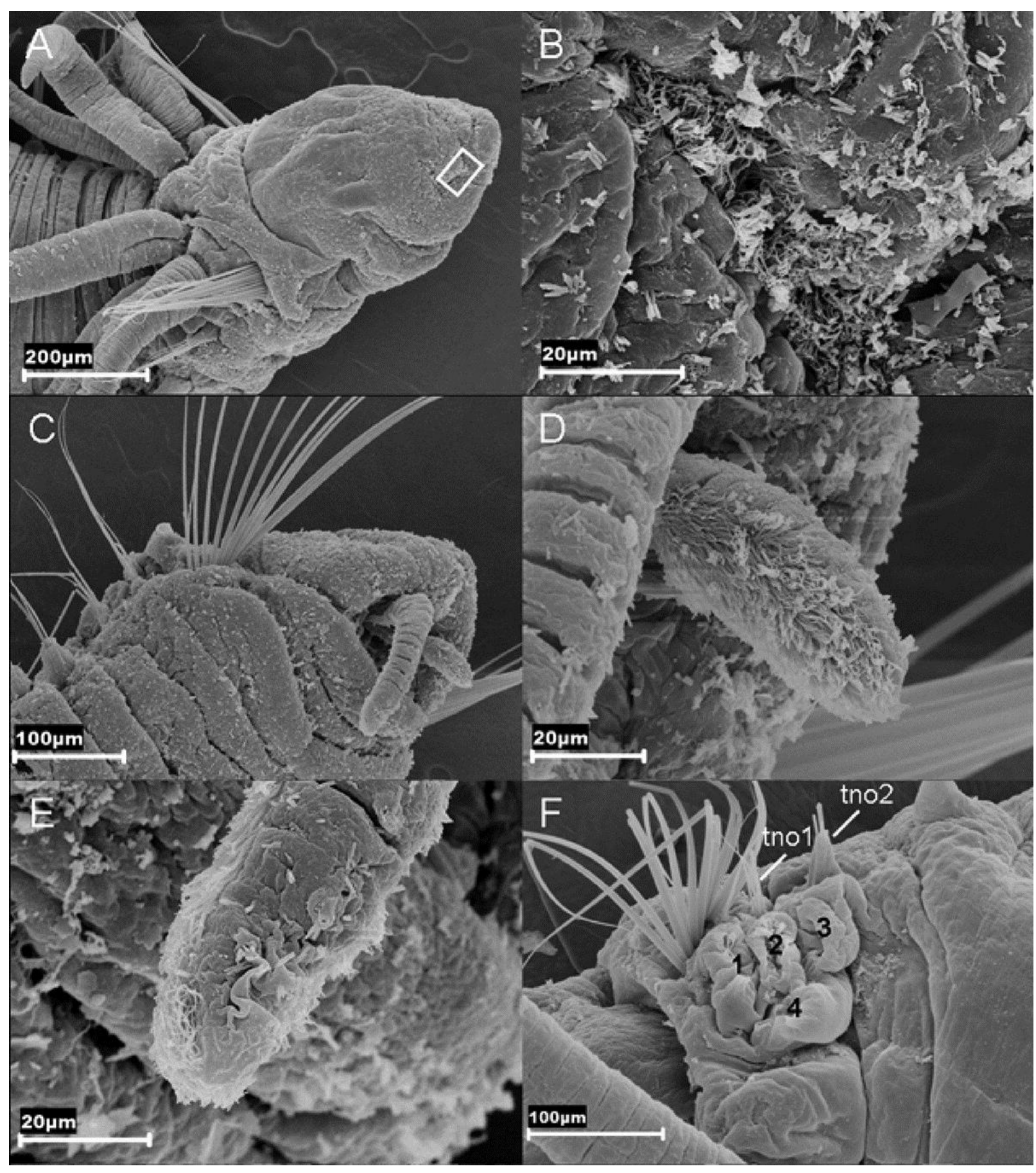

Figure 7. Amphicteis vestis Hartman, 1965. Scanning electron micrographs from IMNH 24083. (A) Anterior end in dorsal view; (B) ciliated nuchal pit; (C) ventral view of anterior end; (D) detail of ciliated side of buccal tentacle; (E) detail of non-ciliated side of buccal tentacle; (F) basal scars of right branchiae (numbered). Abbreviations: tno, thoracic notopod. 


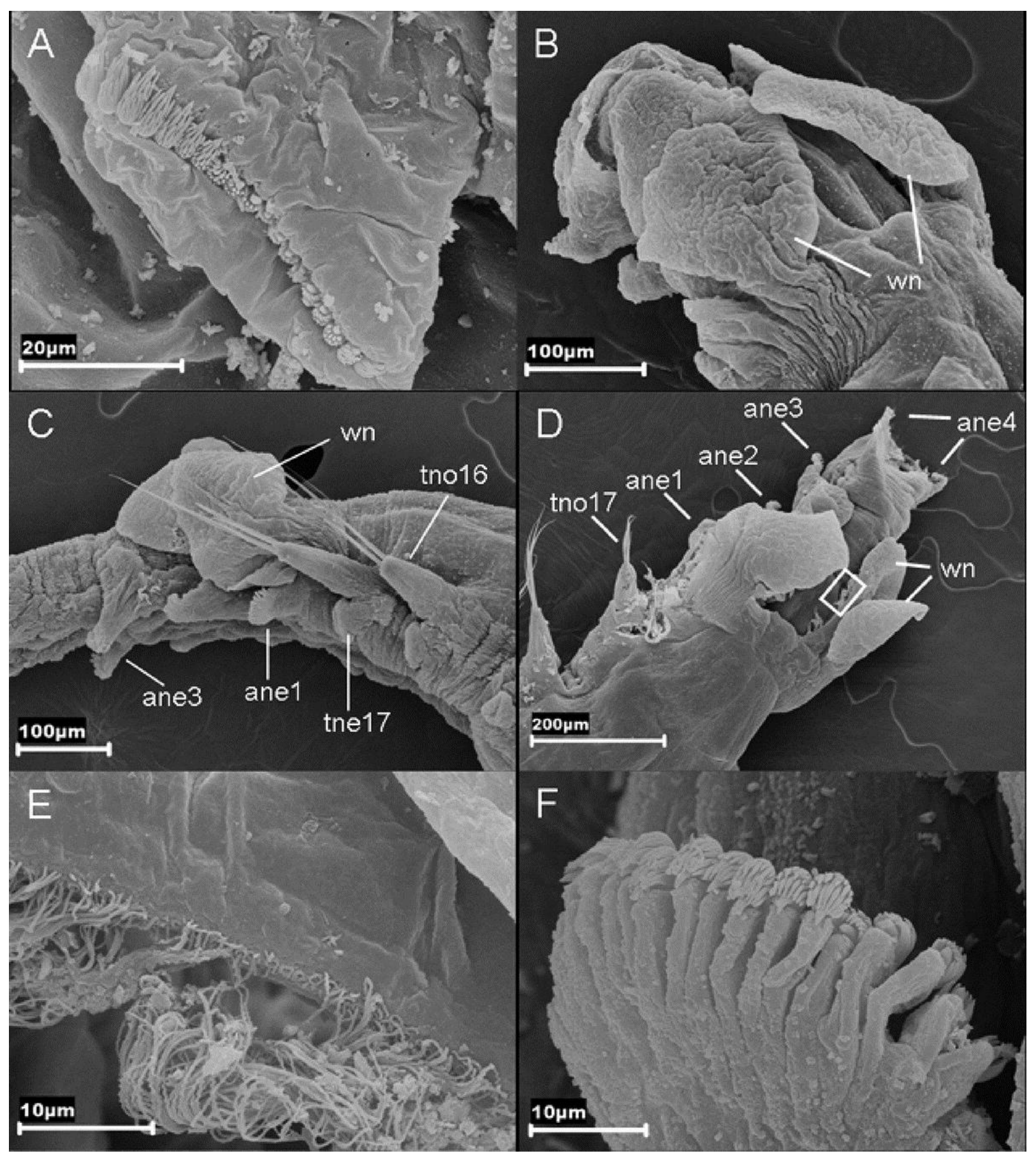

Figure 8. Amphicteis vestis Hartman, 1965. Scanning electron micrographs from IMNH 24084. (A) Tenth thoracic neuropodia and uncini; (B) first abdominal chaetiger, dorsal view of winged expansion of notopod; (C, D) lateral and dorsal views of transitional zone between thorax and abdomen; (E) detail of ciliature present on inner edge of winged notopodia; (F) first abdominal neuropodia and uncini. Abbreviations: wn, winged notopodia of first abdominal chaetiger; tno, thoracic notopod; tne, thoracic neuropod; ane, abdominal neuropod.

\section{Occurrence}

In all, 730 specimens of A. vestis $(40.80 \%$ of the total) were collected in 65 BIOICE samples. Amphicteis vestis is present at a wide range of depths and, to a lesser extent, of temperatures, but is more frequent in warm waters of the continental shelf and upper slope of the southwestern coast of Iceland (Figure 1). Depth range: $37-2295 \mathrm{~m}$; temperature range: $2.34-7.41^{\circ} \mathrm{C}$. Given the small body 
size and fragility of this species coupled with its high quantitative presence in the finest fractions of BIOICE samples $(0.5 \mathrm{~mm})$, it is likely that this species has been overlooked in previous benthic studies conducted in its area of distribution (see below).

\section{Reported distribution}

Amphicteis vestis has been scarcely reported since its original description by Hartman (1965); it has, however, a wide distributional range. Originally described off New England (West Atlantic Ocean), between 200 and $2469 \mathrm{~m}$ depth, it was later reported by Kucheruk (1976) from deeper waters (3240 $3350 \mathrm{~m}$ ) off Alaska Bay (Aleutian Arc, Northeast Pacific) and recently by M. Schüller and B. Ebbe (ANDEEP-SYSTCO, preliminary results on line) from deep Antarctic waters below $2000 \mathrm{~m}$ depth. Recently, one of us (I.J.) had the opportunity to examine Antarctic specimens and tried to find Kucheruk's material in the Shirshov Institute collections where it was supposedly deposited but with no success in the latter case.

\section{Remarks}

The presence of dorsal body features is not rare among the ampharetids. One type of these dorsal features is the so called "elevated notopodia" (Holthe, 1986a.:28), which are present in a variety of genera such as Anobothrus Levinsen, 1884 [Anobothrella Hartman, 1967 syn. and Sosanides HartmannSchröder, 1965. syn., sensu Jirkov

(2001)], Sosane Malmgren, 1866. [Sosanella Hartman, 1965. syn., Sosanopsis Hessle, 1917 syn., Mugga Eliason, 1955 syn. $\quad$ and Mugoides Hartman, 1965 syn., sensu Jirkov and Eclysippe Eliason, 1955. Other types of body modification are the "dorsal ridges" present in Melinnampharete Annenkova, 1937 [Neosamytha Hartman, 1967 syn. sensu Jirkov (2001)] and the "fan-shaped notopodia" present in Jugamphicteis Fauchald and Hancock, 1981, Ymerana Holthe, 1986 and Zatsepinia Jirkov, 1986. Some of these genera have previously been reported from Icelandic waters (see Wesenberg-Lund, 1951) and were also found among the ampharetid material from the BIOICE samples, which is currently being studied by the authors.

According to the key to the Ampharetidae genera provided by Reuscher et al. (2009), the presence of this special body feature in the first abdominal chaetiger in A. vestis would locate the species in the genus Jugamphicteis created by Fauchald and Hancock (1981) and later emended by Holthe (2000). This genus is, to date, composed of four species, namely J. sibogae (Caullery, 1944), J. sargassoensis (Hartman and Fauchald, 1971), J. paleata Fauchald and Hancock, 1981 and J. galatheae Holthe, 2000. All Jugamphicteis species share two synapomorphies (Holthe, 2000:60): presence of prominent nuchal ridges in the prostomium and notopodial fans in the first abdominal chaetiger. Amphicteis vestis shares with the genus Jugamphicteis the following features: number and shape of paleae and branchiae, number of thoracic and abdominal chaetigers and presence of modified notopodia in the first abdominal chaetiger. Fauchald and Hancock (1981:40) and Holthe (2000:60) pointed out, however, that this species should not be placed in Jugamphicteis because of the presence of ciliated nuchal pits in A. vestis instead of nuchal ridges and of bilobed foliose notopodia in the first abdominal chaetiger rather than a valve-like pair. The modified notopodia of A. vestis show other relevant differences to those of Jugamphicteis species. In Jugamphicteis they result from the fusion of most of the notopodial folds of the right and left chaetigers, determining a thin, non-muscular membrane at the inner dorsal sides of both folds, leaving free only the dorsalmost part of each fold which ultimately results in a "valve-like" structure sensu Fauchald and Hancock (1981:41). On the contrary, in A. vestis the pairs of notopodial fans are well-delimited from each other and from those of the other side, hence constituting a "bilobed" structure sensu Fauchald and Hancock (1981). Besides, blunt projections are present on the free margins on the dorsal outer sides of the folds in 
all Jugamphicteis species; these are simple in J.paleata and J. sibogae, double in J. galatheae and probably also double in J. sargassoensis. In A. vestis, both lappets are completely free from each other and bear no projections on the lateral margins.

The ciliature observed on the inner free margins of the lateral lappets in A. vestis has never been reported in any ampharetid species. Its biological role is as yet unknown but it is possible that it helps in ventilating the tube.

The presence of fan-shaped notopodia in the thorax-abdomen transitional zone has also been reported in the ampharetid genus Ymerana Holthe, 1986. Ymerana pteropoda was described as a new genus and species from the Norwegian and Polar seas by Holthe (1986c), who characterized this taxon by the "last pair of (thoracic) notopodia achaetous and transformed into a flattened fan with dorsal lateral wings and ridge across dorsum". This wing-like notopodium is similar to that of A. vestis although in the latter that structure is present as two pairs instead of one. Furthermore, the genus Ymerana has three pairs of branchiae, no paleae and 14 thoracic chaetigers with notopodia, with the last pair transformed in the aforementioned way, whereas A. vestis has four pairs of branchiae, long and numerous paleae, 17 thoracic notopodia and the fan-like notopodial structure represents the first abdominal chaetiger instead of the last thoracic chaetiger.

Zatsepinia rittichae Jirkov, 1986, collected from the northern Norwegian coasts and at both sides of the GIF Ridge, also has elevated notopodia but differs from A. vestis in having those structures in the 11th thoracic chaetiger (12 thoracic chaetigers in total), in lacking paleae and in having two pairs of branchiae.

Following the comments mentioned above and the diagnosis of the genus Amphicteis, we agree with Jirkov (2008) that the affinities of A. vestis with the genus Amphicteis remain highly uncertain. Hence, the shape of the prostomium, with a pair of ciliated pits (nuchal organs?) instead of the characteristic longitudinal ridges, the buccal tentacles being ciliated instead of smooth, the presence of a unique double dorsal fan in the first abdominal chaetiger and the different shape of both thoracic and abdominal uncini (with one vertical row of teeth in Amphicteis as opposed to multiple rows in A. vestis) suggest that this species belongs neither to Amphicteis nor Jugamphicteis. Nevertheless, so as not to create more confusion in a highly diverse family with the erection of a new monotypic genus, we decided to maintain the species in Amphicteis pending a much needed revision of the genus.

\section{Amphicteis wesenbergae sp. nov.}

(Figures 1, 9, 10)

\section{Type material}

\section{Holotype}

Zoologisk Museum: ZMUC-POL-1871. "Ingolf" Expedition station 117, east Norwegian Sea $\left(69^{\circ} 13^{\prime} \mathrm{N} ; 08^{\circ} 23^{\prime} \mathrm{W}\right), 1889 \mathrm{~m}$ depth. The specimen was formerly identified as A. gunneri.

\section{Paratypes}

Icelandic Museum of Natural History (Reykjavik): IMNH 24085 (BIOICE sample 2018; 15 paratypes); IMNH 24086 (2704; three paratypes); IMNH 24087 (2776; 15 paratypes); IMNH 24088 (2777; one paratype); IMNH 24089 (2844; three paratypes); IMNH 24090 (2863; one paratype); IMNH 24091 (2903; one paratype); IMNH 24092 (3210; one paratype); IMNH 24093 (3519; one paratype); IMNH 
24094 (3595; one paratype); IMNH 24095 (3628; three paratypes); IMNH 24096 (3629; 10 paratypes); IMNH 24097 (3636; one paratype); IMNH 24098 (3657; 28 paratypes).

\section{Additional BIOICE material}

Museo Nacional de Ciencias Naturales (Madrid): MNCN 16.01/13264 (BIOICE sample 3222; 235 specimens). Zoologisk Museum (Copenhagen): ZMUC-POL-2147 (BIOICE sample 3624; 10 specimens).

\section{Other material examined}

East Greenland: R/V Sevastopol, cruise 10, station $1725\left(67^{\circ} 32^{\prime} \mathrm{N} ; 13^{\circ} 15^{\prime} \mathrm{W}\right), 1730 \mathrm{~m},-0.89^{\circ} \mathrm{C}$ (one specimen). R/V Sevastopol, cruise 15, station $2448\left(69^{\circ} 20^{\prime} \mathrm{N} ; 12^{\circ} 00^{\prime} \mathrm{W}\right), 1940 \mathrm{~m},-0.9^{\circ} \mathrm{C}$ (one). $\mathrm{R} / \mathrm{V}$ Tunetz, cruise 105 , station $16\left(72^{\circ} 50^{\prime} \mathrm{N} ; 14^{\circ} 00^{\prime} \mathrm{W}\right), 960 \mathrm{~m},-0.96^{\circ} \mathrm{C}$ (one). West Norway: $\mathrm{R} / \mathrm{V}$ Tunetz, cruise 105 , station $6\left(68^{\circ} 00^{\prime} \mathrm{N} ; 10^{\circ} 00^{\prime} \mathrm{W}\right), 260 \mathrm{~m}, 6.06^{\circ} \mathrm{C}$ (one).

\section{Description based on holotype}

Holotype $9 \mathrm{~mm}$ long and $1 \mathrm{~mm}$ wide at thorax level. Additional material $7-12 \mathrm{~mm}$ long and $0.8-2 \mathrm{~mm}$ wide. Thorax and abdomen well defined; thorax about 1.5 times the width and length of abdomen (Figure 9A); barely tapering towards posterior part. Prostomium of Amphicteis-type (Figure 10A) with
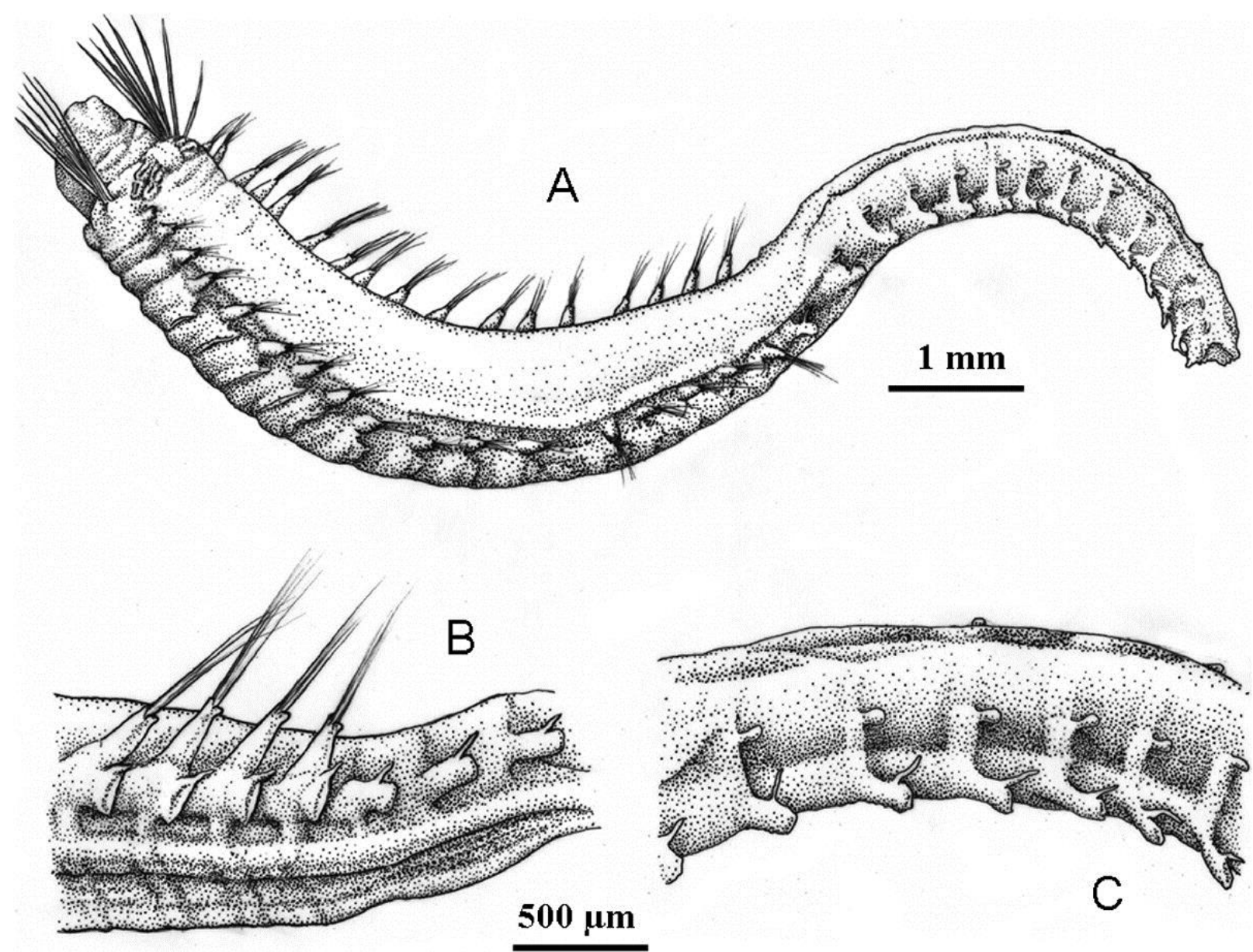

Figure 9. Amphicteis wesenbergae sp. nov. Holotype (ZMUC-POL-1871). (A) Dorso-lateral view; (B) thoraxabdomen transition, lateral view; (C) abdominal chaetigers, lateral view. 
a pair of dorsal longitudinal ridges, less obvious than in A. gunneri, and a pair of well-marked transverse nuchal grooves. No eyes seen. Four pairs of long, tapering and deciduous branchiae (all missing in holotype) separated in left and right groups and arranged in two pairs, the posterior pair slightly displaced mid-dorsally (Figure 10A). Eight to ten long and slender paleae with tapering ends (Figure 10A, B). Seventeen thoracic chaetigers with large notopodia provided with long notochaetae (Figures 9A, 10C); the posterior 14 also with neuropodia provided with dorsal cirri (Figure 9B) and uncini with a single row of teeth. Fifteen abdominal chaetigers provided with large notopodial rudiments, and neuropodia with long dorsal cirri (Figures 9C, 10D, E) and uncini with single row of teeth (Figure 10F). Pygidium with a pair of long lateral cirri. Colour in alcohol pale yellow. Tubes made of mud with some foraminiferans incrusted.

\section{Occurrence}

In all, 330 specimens of $A$. wesenbergae sp. nov. (18.45\% of the total) were collected in 16 BIOICE samples. Amphicteis wesenbergae sp. nov. is present in the warm waters of the deep slope off the southwestern coast of Iceland (Figure 1C). Depth range: 916-2544 m; temperature range: -0.87 to $5.52^{\circ} \mathrm{C}$. The species was also found further north in east Greenland and in the Norwegian Sea (see above).

\section{Remarks}

Hartley (1985:314) noted that “... a range of specimens attributed to A. gunneri from Greenland, Iceland and the deeper North Atlantic ... found to consist of several closely related species of Amphicteis". In fact, the specimen selected as holotype of A. wesenbergae sp. nov., located in the ZMUC polychaete collection, was originally labelled as A. gunneri. Amphicteis wesenbergae sp. nov. belongs to the group of Amphicteis species with narrow, evenly tapered paleae, which also includes A. gunneri and A. sundevalli. In fact, A. wesenbergae sp. nov. and A. gunneri have the same number of abdominal chaetigers, and look very similar to each other at first sight. Nevertheless, both species can be easily distinguished by the length of the dorsal cirri on the abdominal neuropodia: long in A. wesenbergae sp. nov. and short in A. gunneri (compare Figure 2D with Figure 10E).

\section{Etymology}

The species is dedicated to the Danish Zoologist Elise Wesenberg-Lund (1896-1969) for her remarkable contributions to the taxonomy of polychaetes of Iceland and Greenland.

\section{Key to Arctic-Boreal species of Amphicteis}

1. Notopodia of first abdominal chaetiger transformed into a double dorsal fan A. vestis $^{1}$

Notopodia of first abdominal chaetiger not transformed. .2

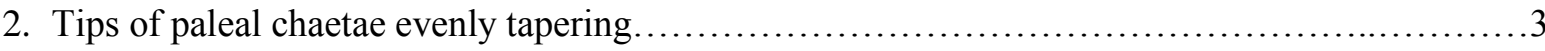

Tips of paleal chaetae blunt................................................................

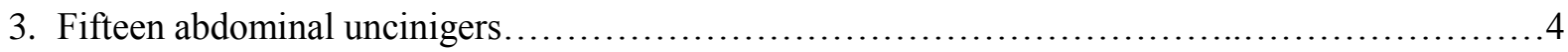

Between 18 and 20 abdominal uncinigers (upper shelf, high Arctic distribution)........... sundevalli ${ }^{2}$ 
4. Abdominal uncinigers with short dorsal cirrus; longitudinal ridges of prostomium well marked (widely distributed)

A. gunneri

Abdominal uncinigers with long dorsal cirrus; longitudinal ridges of prostomium inconspicuous A. wesenbergae sp. nov.

5. Paleal chaetae dark brown; usually more than 10 (8-16) on each side (bathyal, Arctic distribution). A. ninonae

Paleal chaetae light yellow; usually up to eight (10) on each side (shallow waters, low boreallusitanian distribution) A. midas $^{2}$

Descriptions of A. midas and A. sundevalli can be found in Hartley (1985:309), Holthe (1986b:58) and Jirkov (2001:473).

\section{Acknowledgements}

The senior author (J.P.) wishes to thank Danny Eibye-Jacobsen, Majken Them Tøttrup (ZMUC), Elin Sigvaldadóttir and Karin Sindemark (SMNH) for their help during his stay at both institutions. Igor Jirkov also acknowledges David Hall and Tim Worsfold, Unicomarine Ltd., Letchworth Hertfordshire, $\mathrm{UK}$, for the loan of specimens of A. midas for examination. Special thanks to Solrun Bragadóttir and all the women of the SMC involved in sorting of specimens from the BIOICE samples. Ada Castro and Catalina Sueiro (SAIN, UDC) for assisting in the preparation of specimens and use of the SEM, David Romero (UDC) for the line drawings and Noela Sánchez (UDC) for the preparation of maps. Constructive comments by M. Schüller and B. Ebbe are gratefully acknowledged.

This work was partially supported by several grants from the European Union's TMR programme and the UDC and Xunta de Galicia to J.P. to visit the SMC. J.P. also gratefully acknowledges Synthesis support made available by the European Community - Research Infrastructure Action under the FP6 Structuring the European Research Area (Projects DK-TAF-3118 and SE-TAF4599) to visit the Zoologisk Museum (Copenhagen), and the Swedish Museum of Natural History (Stockholm).

\section{Notes}

1. Most probably, this species does not belong to the genus Amphicteis (see Remarks section for this species).

2. Species not reported in Icelandic waters and not found among BIOICE material.

\section{References}

Annenkova N. 1929. Beiträge zur Kenntnis der Polychaeten-Fauna der USSR. 1. Fam. Pectinariidae Quatrefages (Amphictenidae Malmgren) und Ampharetidae Malmgren. Annu Rep Mus Zool Acad Sci USSR. 30:477-502. Augener H. 1928. Die Polychaeten von Spitzbergen. Fauna Arctica. 5:647-834.

Bellan G. 2001. Polychaeta. In: Costello MJ. et al. editors. European register of marine species: a check-list of the marine species in Europe and a bibliography of guides to their identification. Paris (France): Muséum national d'Histoire naturelle. 214-231. [Collection Patrimoines Naturels, no 50.]

Brix S, Svavarsson J. 2010. Distribution and diversity of desmosomatid and nannoniscid isopods (Crustacea) on the Greenland-Iceland-Faeroe Ridge. Polar Biol. 33:15-530.

Chambers SJ, Woodham A. 2003. A new species of Chaetozone (Polychaeta: Cirratulidae) from deep water in the northeast Atlantic, with comments on the diversity of the genus in cold northern waters. Hydrobiologia. 496:41-48. 
Day JH. 1964. A review of the family Ampharetidae (Polychaeta). Ann South Afr Mus. 48:97-120.

Deubel H. 2000. Struktureigenschaften und Nahrungsbedarf der Zoobenthosgemeinschaften im Bereich des Lomonossowrückens im Arktischen Ozean. Ber Polarforsch. 370:1-147 (in German with English summary).

Ditlevsen HJ. 1929. Polychaeta. Zool Faeroes. 16:1-83.

Ditlevsen HJ. 1937. Polychaeta. The "Godthaab” Expedition. Meddel Grønland. 80:1-64.

Einarsson H. 1941. Survey of benthonic animal communities of Faxa Bay (Iceland). Meddel Komm Danmarks Fisk Havundersøgelser, Fisk. 11:1-46.

Fauchald K. 1977. The polychaete worms. Definitions and keys to the orders, families and genera. Nat Hist Mus LA County (ed.) Sci Ser. 28:1-188.

Fauchald K, Hancock DR. 1981. Deep-water polychaetes from a transect off central Oregon. Allan Hancock Foundation Monogr. 11:1-73.

Fauvel P. 1927. Polychètes sédentaires. Addenda aux errantes, Archiannélides, Myzostomaires. In: Faune de France. Paris (France): Fédération Française des Sociétés de Sciences Naturelles. Office Central de Faunistique. 16:1-492 pp.

Hansson HG. 1998. NEAT (North East Atlantic Taxa): South Scandinavian marine Annelida Check-list [Internet]. Tjärnö (Sweden): Tjärnö Marine Biological Laboratory. $28 \quad$ February 2011. http://www.tmbl.gu.se/libdb/taxon/neat_pdf/NEAT*Annelida.pdf

Hartley JP. 1985. The re-establishment of Amphicteis midas (Gosse, 1855) and redescription of the type material of A. gunneri (M. Sars, 1835) (Polychaeta: Ampharetidae). Sarsia. 70:309-315.

Hartman O. 1959. Catalogue of the polychaetous annelids of the world. Allan Hancock Foundation Publ, Occas Paper. 23:1-197.

Hartman O. 1965. Deep-water benthic polychaetous annelids off New England to Bermuda and other North Atlantic Areas. Allan Hancock Foundation Publ, Occas Paper. 28:1-378.

Hartmann-Schröder G. 1996. Annelida, Borstenwürmer, Polychaeta. 2nd edn. Die Tierwelt Deutschlands, 58, Jena: Gustav Fischer. 648pp.

Hessle C. 1917. Zur Kenntnis der terebellomorphen Polychaeten. Zool Bidr Uppsala. 5:39-258.

Holthe T. 1986a. Evolution, systematics, and distribution of the Polychaeta Terebellomorpha, with a catalogue of the taxa and a bibliography. Gunneria. 55:1-236.

Holthe T. 1986b. Polychaeta Terebellomorpha. Marine Invert Scand. 7:1-194.

Holthe T. 1986c. Polychaeta Terebellomorpha from the northern Norwegian Sea and the Polar Sea, with descriptions of Mugga bathyalis sp. n. and Ymerana pteropoda gen. and sp. n. Sarsia. 71:227-234.

Holthe T. 2000. Bathyal and abyssal Ampharetidae (Annelida: Polychaeta) (Sedentary species II). Galathea Rep. 18:57-68.

Hutchings P. 2000. Family Ampharetidae. In: Beesley PL, Ross GJB and Glasby CJ. editors Polychaetes and Allies: The Southern Synthesis. Fauna of Australia, 4A Polychaeta, Myzostomida, Pogonophora, Echiura, Sipuncula. Melbourne: CSIRO Publishing. p.204-208.

Imajima M. 2001. Deep-Sea Benthic Polychaetous Annelids of Tosa Bay, Southwestern Japan. In: Fujita T. et al. editor. Deep-Sea Fauna and Pollutants in Tosa Bay. Tokyo: National Science Museum Monographs. 20:31100 .

Jirkov IA. 1985. Amphicteis ninonae sp. n. (Polychaeta, Ampharetidae) from the northern waters. Zool Zh. 64:1894-1897 (in Russian with English summary).

Jirkov IA. 1989. Bottom fauna of the USSR. Polychaeta. Moscow: Moscow State University Press. (English translation from Russian).

Jirkov IA. 2001. Polychaeta of the Arctic Ocean. Moscow: Yanus-K (in Russian).

Jirkov IA. 2008. Revision of Ampharetidae (Polychaeta) with modified thoracic notopodia. Invert Zool. 5:111132.

Kirkegaard JB. 2001. Polychaetes of the families Glyceridae, Goniadidae, and Nereididae from the North Atlantic around Iceland. Sarsia. 8:13-20.

Kucheruk NV. 1976. Polychaetous Annelids of the family Ampharetidae from deep-water part of Alaska Bay. Trudy Inst Okeanol. 99:91-101 (in Russian with English summary).

Mackie, ASY. 1994. Adercodon pleijeli gen. et sp. nov. (Polychaeta, Ampharetidae) from the Mediterranean Sea. Mém Mus natl Hist nat. 162:243-250. 
Malmgren AJ. 1866/1865. Nordiska Hafs-Annulater. Oefversigt af K Vetenskaps-Akademiens Förhandlingar. 22:355-410.

Parapar J. 2003. Oweniidae (Annelida, Polychaeta) from Icelandic waters, collected by the BIOICE project, with the description of Myrioglobula islandica n. sp. Sarsia. 88:274-290.

Parapar J. 2006. The genera Myriochele and Myrioglobula (Polychaeta, Oweniidae) in Icelandic waters with the revision of type material of Myriochele heeri Malmgren, 1867 and the description of a new species. J Nat Hist. 40:523-547.

Reuscher M, Fiege D, Wehe T. 2009. Four new species of Ampharetidae (Annelida: Polychaeta) from Pacific hot vents and cold seeps, with a key and synoptic table of characters for all genera. Zootaxa. 2191:1-40.

Saemundsson B. 1918. Bidrag til kundskapen om Islands polychaete børsteorme (Annulata polychæta Islandiæ). Vidensk Meddel Dansk Naturhist Forening. 69:165-241.

Sanfilippo R. 2001. Bathyvermilia islandica (Polychaeta, Serpulidae): new species from the southern Icelandic Sea. Sarsia. 86:177-182.

Sars M. 1835. Beskrivelser og Iagttagelser over nogle mærkelige eller nye i Havet ved den Bergenske Kyst Levende Dyr af Polypernes, Acephalernes, Radiaternes, Annelidernes og Moluskernes Classer med en kort Oversigt over de hidtil af Forfatten sammesteds fundne Arter og deres Forekommen. Bergen.

Schüller M, Ebbe B. Indications for cryptic speciation in the Southern Ocean Ampharetidae and Trichobranchidae (Annelida, Polychaeta). ANDEEP-SYSTCO (SYSTem COupling) System Coupling in the deep Southern Ocean [Internet]. Available from Bremerhaven (Germany): Alferd-Wegener-Institut für Polar und Meeresforschung. 28 February 2011. http://epic.awi.de/Publications/Bat2010a.pdf.

Sigvaldadóttir E. 2002. Polychaetes of the genera Prionospio and Aurospio (Spionidae, Polychaeta) from Icelandic waters. Sarsia. 87:207-215.

Spärck R. 1937. The benthonic animal communities of the coastal waters. Zool Iceland. 6:1-45.

Weisshappel JB. 2000. Distribution and diversity of the hyperbenthic amphipod family Eusiridae in the different seas around the Greenland-Iceland-Faeroe-Ridge. Sarsia. 85:227-236.

Wesenberg-Lund E. 1950. Polychaeta. The Danish Ingolf Expedition. 4:1-92.

Wesenberg-Lund E. 1951. Polychaeta. Zool Iceland. 2:1-182. 